\title{
New reports of host plants of Euchistus nicaraguensis Rolston, 1972 (Heteroptera: Pentatomidae) and natural parasitism of Telenomus podisi Ashmead, 1893 (Hymenoptera: Platygastridae) in the rice agricultural ecosystem in Panama
}

\author{
B. Zachrisson ${ }^{a *}, J$. Grazia ${ }^{b}$, P. Polanco ${ }^{c}$ and P. Osorio ${ }^{a}$ \\ aLaboratório de Entomología, Programa de Investigación de Recursos Genéticos y Biodiversidad, Instituto de \\ Investigación Agropecuaria de Panamá - IDIAP, Carretera Interamericana, El Naranjal, Chepo, Panamá, Panamá \\ 'Laboratório de Entomologia Sistemática, Departamento de Zoología, Universidade Federal do Rio Grande do Sul - \\ UFRGS, Avenida Bento Gonçalves, 9500, Prédio 43435.2, CEP 91501-970, Porto Alegre, RS, Brazil \\ 'Programa Regional de Maestría en Entomología, Universidad de Panamá - UP, Ciudad Universitaria “Octavio Méndez \\ Pereira", Estafeta Universitaria, Panamá, Panamá \\ *e-mail: bazsalam@gmail.com
}

Received: October 18, 2016 - Accepted: February 10, 2017 - Distributed: October 31, 2018

The subfamily Pentatominae, which includes Euschistus nicaraguensis Rolston, 1972, presents 116 genera and aproximately more than 667 species, reported for the Neotropical region (Grazia et al., 2015). The geographical distribution of this species comprehends diverse countries in Central America, between Panama and Honduras (Rolston, 1974), reporting species of weeds in rice crops (Rolston, 1974; Maes, 1994). In spite of the occurrence reports of E. nicaraguensis, of rice crops in Panama (Rolston, 1974; Maes, 1994; Arismendi, 2002), the presence of this species of Pentatomidae is sporadic and its population reduced. Nevertheless, the colonization, adaptation, and biological development of E. nicaraguensis with the species complex of weeds associated with the agricultural ecosystem of rice, have been least studied. In a similar manner, the interaction between the natural control of this insect species with the population of biological control agents and specifically the eggs parasitoids, is considered as a new association between E. nicaraguensis and Telenomus podisi Ashmead, 1893, defined as a fundamental component in the integral management of the agricultural ecosystem of rice. The present report evidences the importance of this species, as a potential insect-pest, to the extent in which the biotic and abiotic factors, among other variables, promote the increase of E. nicaraguensis population.

The identification of the species E. nicaraguensis, was performed by Dr. Jocelia Grazia, from the Department of Zoology, of the Universidade Federal de Rio Grande do Sul, Porto Alegre, Brazil. The samplings were performed in June 2016, in extensive areas of rice production from the IDIAP-38 variety, between the floration and milky stage, in the location of Juan Hombron, province of Cocle, Panama $\left(08^{\circ} 23^{\prime} 83^{\prime \prime} \mathrm{N}\right.$; $\left.08^{\circ} 13^{\prime} 90^{\prime \prime} \mathrm{O}\right)$. The average temperature and relative humidity, in the sampled plots, was $32.8^{\circ} \mathrm{C}$ and $82 \%$, respectively. It is highlighted that the average temperature and relative humidity, in this productive region of rice was of $30.0{ }^{\circ} \mathrm{C}$ and $80 \%$, for the last five year period (2010-2015). The total number of samples collected randomly was 15 , in a crop area of 8 hectares, free from insecticide application. The recollection of eggs and adults of E. nicaraguensis, was performed by means of sweep net and by visual methods. The samples in the complex of host weeds of E. nicaraguensis was performed in areas next to the experimental plot, visually examining and collecting egg masses by square meter $\mathrm{m}^{2}$, totaling 20 samples, in the experimental plots. The collected egg masses were individually placed in glass Petri dishes $(9.0 \times 1.5 \mathrm{~cm})$, maintaining the internal humidity by the moistened filter paper with distilled water, placed at the base. Later, the egg masses were transferred to controlled climate chambers regulated at $28 \pm 1{ }^{\circ} \mathrm{C}$ of temperature, $85 \pm 3 \%$ of relative humidity and 12 hours of photophase, with the purpose of waiting for the emergence of parasitoids. The parasitism rate of eggs, was determined by the formula $\mathrm{P}[(\%=$ number of eggs parasitized /total number of eggs submitted to parasitism) 100]. The nymphs that hatched were maintained under controlled abiotic conditions, until the adult stage was reached and confirmed that the parasitized eggs belong to E. nicaraguensis.

The presence of 48 (30 females and 18 males) adults of $E$. nicaraguensis, were found feeding from rice spikes, at the milky stage, in the experimental plots located at Juan Hombrón, Cocle, Panama. The damage brought about by this insect, is similar to the damage caused by Oebalus insularis Stal, 1872, which affects grain quality as well as the cost effectiveness of the crop (Zachrisson et al., 2014). Regardless, of the reduced quantity of egg masses (3) and adults (48) of E. nicaraguensis, the possibility of colonization, adaptation and development exist for this species in commercial crops of rice. Nevertheless, the parasitism rate of $T$. podisi at $85.5 \%$, confirms the population regulation for this insect, found in the experimental plot of rice, sown with the variety IDIAP-38 (Table 1). The eggs 
Table 1. Parasitism rate of Euschistus nicaraguensis Rolston, 1972 (Heteroptera: Pentatomidae) eggs for Telenomus podisi Ashmead, 1893 (Hymenoptera: Platygastridae) in the rice agricultural ecosystem, in Juan Hombron ${ }^{1}$, Cocle, Panama.

\begin{tabular}{lcccc}
\hline \multicolumn{1}{c}{ Species } & Family & $\begin{array}{c}\text { Total number of } \\
\text { eggs by mass }\end{array}$ & $\begin{array}{c}\text { Total number of } \\
\text { parasitized eggs }\end{array}$ & $\begin{array}{c}\text { Parasitism Rate } \\
(\%)\end{array}$ \\
\hline Oryza sativa & Poaceae & $76(3)^{2}$ & 65 & 85.5 \\
Cyperus rotundus & Cyperaceae & $49(2)$ & 32 & 65.3 \\
Echinochloa colona & Poaceae & $68(3)$ & 29 & 42.6 \\
Eclipa prostrata & Asteraceae & $42(3)$ & 24 & 57.1 \\
Fimbristylis littoralis & Cyperaceae & $36(2)$ & 19 & 52.8 \\
\hline
\end{tabular}

${ }^{1}$ Areas of rice production and complex species of weed in surrounding areas of crops; ${ }^{2}$ Number of egg masses of E. nicaraguensis.

parasitism of E. nicaraguensis, registered in the complex of weeds surrounding areas, varies between 65.0 and $42.0 \%$ (Table 1), which indicate the reduced insect population in the rice fields, which can be considered a reservoir of T. podisi, between the periods of planting.

The obtained data, justify the reassessment of the integrated pest management programs (IPM), from the egg incidence, nymphs and adults of E. nicaraguensis, present in the complex of weeds of the Asteraceae family (Eclipta prostrata L.), Cyperaceae (Cyperus rotundus L.), Cyperaceae (Fimbristylis littoralis L.), Poaceae (Echinochloa colona Link), in the rice production areas, in Panama. The possible adaptation of E. nicaraguensis in this agricultural ecosystem and the consequent increase in the number of generations, at medium and long term, could also be attributed to global warming, considering other biotic variables.

Kiritani (2006) registered the population increase in diverse speciess of Pentatomidae in Japan, claiming this phenomenon to climatic variability. However, the elevated parasitism rate of $T$. podisi, registered in eggs of E. nicaraguensis, suggest the population regulation for this insect, in the assessed plot, that could be complemented with the rational management of the insecticides applications. The trophic interaction observed, between E. nicaraguensis as a possible potential insect-pest and $T$. podisi, provides relevant information for the implementation of biological control programs, strengthening the integrated pest management.

\section{Acknowledgments}

The authors acknowledege to the National Research System (SNI) of the National Secretariat of Science, Technology and Innovation (SENACYT), Republic of Panama, for the financial support of this study.

\section{References}

ARISMENDI, N., 2002. Pentatomidae en Honduras: Listado, distribución y biología de especies. Honduras: Escuela Agrícola Panamericana, 42 p. Tesis de Licenciatura de Ingeniero Agrónomo.

GRAZIA, J., PANIZZI, A.R., GREVE, C., SCHWERTNER, C.F., CAMPOS, L.A., GARBELOTTO, T.A. and FERNANDES, J.A.M., 2015. Stink bugs (Pentatomidae). In: A.R. PANIZZI and J. GRAZIA, eds. True Bugs (Heteroptera) of the Neotropics. Holland: Springer, pp. 681-750.

KIRITANI, K., 2006. Predicting impacts of global warning on population dynamics and distribution of arthropods in Japan. Population Ecology, vol. 48, no. 1, pp. 5-12. http://dx.doi. org/10.1007/s10144-005-0225-0.

MAES, J.M., 1994. Catálogo de los Pentatomoidea (Heteroptera) de Nicaragua.: Print-León, pp. 1-19. vol. 28.

ROLSTON, L.H., 1974. Revision of the genus Euschistus in Middle America (Hemiptera: Pentatomidae, Pentatominae). Entomologica Americana, vol. 48, no. 1, pp. 23-25.

ZACHRISSON, B., POLANCO, P. and MARTÍNEZ, O., 2014. Desempeño biológico y reproductivo de Oebalus insularis Stal (Hemiptera: Pentatomidae), en diferentes plantas hospedantes. Revista de Protección Vegetal, vol. 29, no. 2, pp. 77-81. 